\title{
Supplementation of native grass hay with cowpea (Vigna unguiculata) hay, wilted leucaena (Leucaena leucocephala) forage, wilted tagasaste (Chamaecytisus palmensis) forage or a wheat middling for young Friesian x Zebu (Boran) crossbred steers
}

\author{
Tuomo VarvikKo, Hannele Khalili and Seamus Crosse
}

\begin{abstract}
VARVIKKo, T., KHALIII, H. \& Crosse, S. 1992. Supplementation of native grass hay with cowpea (Vigna unguiculata) hay, wilted leucaena (Leucaena leucocephala) forage, wilted tagasaste (Chamaecytisus palmensis) forage or wheat middling for young Friesian x Zebu (Boran) crossbred steers. Agric. Sci. Finl. 1: 247-254. (International Livestock Centre for Africa (ILCA), P.O.Box 5689, Addis Ababa, Ethiopia.)
\end{abstract}

\begin{abstract}
A 100-day experiment of a randomized block design was conducted with forty Friesian $\mathrm{x}$ Zebu (Boran) crossbred growing steers to compare the value of wheat middling, an agro-industrial by-product (diet W), cowpea (Vigna unguiculata) hay (diet C), and wilted forages of leucaena (Leucaena leucocephala, diet L) and tagasaste (Chamaecytisus palmensis, diet T) as cattle feed. These feeds were fed daily at a level of $1.5 \mathrm{~kg}$ (on an air dry basis) to supplement the basal diet (diet $\mathrm{H}$ ) of native hay. A mineral supplement containing $50 \mathrm{~g}$ bone meal and $10 \mathrm{~g}$ common salt was also given daily. The steers were group-fed, but during the last two weeks at the end of the experiment the animals were housed individually in feeding pens to estimate the feed intake and apparent digestibilities of the diets. The animals were weighed at the beginning of the experiment, thereafter every two weeks, and finally at the end of the experiment.

The animals consumed all the offered supplements, except for tagasaste forage, of which one third remained unconsumed. The mean daily total dry matter intake during the individual feeding period ranged from 4.0 to $5.0 \mathrm{~kg}$ between the diets $(\mathrm{P}<0.01)$. As to metabolizable energy and crude protein intakes, diet W ranked first, followed by diets $\mathrm{L}, \mathrm{C}, \mathrm{T}$ and $\mathrm{H}$ in descending order. The daily weight gain $(\mathrm{g})$ was highest on diet W (411) again followed by diets L (371), C (236), H (86) and T (62). It was concluded that poor palatability may be a major problem in feeding tagasaste to growing cattle.
\end{abstract}

Key words: leucaena, tagasaste, cowpea, wheat middling, growing steers

\section{Introduction}

In the Ethiopian highlands, smallholder farmers harvest grass for hay after the long rains which last from mid June to end September. The harvesting time often extends from mid October to early January. The hay is used as the basal feed during the following critical dry period. The long harvesting time causes a decline in hay quality. The protein content of native hay is usually $6 \%$ or less of dry matter (DM), cell wall contents range between $75 \%$ and $80 \%$, and DM digestibility is below $50 \%$ (SEYoum and Zinash, 1989). Therefore, supplementary feeding is necessary to meet the energy 
and protein demands of animals above the maintenance requirement.

Cowpea (Vigna unguiculata) hay provides a farm-produced alternative with good digestibility and high protein content. Forages of Leguminosae fodder trees such as leucaena (Leucaena leucocephala) and tagasaste (Chamaecytisys palmensis) also rank high as to protein content and digestibility. In spite of its mimosine content, leucaena is generally considered as a good feed for ruminants (BENGE 1980). Tagasaste is a novel feed for ruminants, which should have good potential as a supplement to low-quality crop residues or hay (LAMBERT et al. 1989, 1989a; BorENS and POPPI 1990). These supplementary feeds may be expected to notably improve the nutritive value of the onfarm produced diet for cattle in the East African highlands.

The feeding value of these feeds, in relation to each other or to common agro-industrial by-products such as wheat middling, has so far not been established for ruminants. The present study was designed to compare the value of cowpea, wilted leucaena forage, wilted tagasaste forage and wheat middling as energy and protein supplements for growing crossbred steers fed on native grass hay.

\section{Material and methods}

\section{Animals and their diets}

A total of forty growing Friesian $x$ Zebu (Boran) steers were used in a randomized block design experiment. Their average initial live weight was $141 \mathrm{~kg}$ (SEM 5.6). The animals were blocked on live weight, and randomly assigned to five dietary treatments. All the animals were fed a basal diet composed of native hay and water ad libitum, as well as a mineral supplement consisting of $50 \mathrm{~g}$ bone meal and $10 \mathrm{~g}$ common salt. The different dietary treatments were:

diet $\mathrm{H}$, basal diet of native hay (control diet); diet $\mathrm{W}$, basal diet plus wheat middlings;

diet $\mathrm{C}$, basal diet plus cowpea hay;

diet L, basal diet plus wilted leucaena forage; diet $\mathrm{T}$, basal diet plus wilted tagasaste forage.

The supplement was fed at a level of 1.5 $\mathrm{kg} / \mathrm{animal} /$ day (on an air dry basis). Leucaena and tagasaste forages consisted of leaves and edible stems, with respective leaf to stem ratios of 3:1 and $1: 1$. The stem diameter was less than $5 \mathrm{~mm}$ for both feeds. Cowpea was given in the form of long hay. The animals were group-fed twice a day, at 07.00 and 15.00 hours, and the experimental period was 100 days.

\section{Feed sampling and chemical analyses}

The experimental feeds were sampled weekly, and the samples bulked on a four-week basis into one sample per period for each feed. The samples were analyzed for DM ( $105{ }^{\circ} \mathrm{C}$ for 24 hours), organic matter (OM, ashing at $\left.500{ }^{\circ} \mathrm{C}\right)$, Kjeldahl-N, and fibre fractions (neutral detergent fibre, NDF; acid detergent fibre, ADF; and acid detergent lignin, ADL; GoERING and VAN SOEST 1970).

\section{Determination of rumen degradability of the experimental feeds}

Rumen degradability of the experimental feeds was determined by the nylon bag method. The feeds ( $2.0 \mathrm{~g}$ air dry, milled through a $2.0 \mathrm{~mm}$ screen) were weighed into the polyamide (Polymon, Switzerland, pore size $41 \mathrm{um})$ bags $(6 \times 12 \mathrm{~cm})$. The bags were then incubated in the rumen for $0,6,12,24$, 48 or 72 hours. The incubated bags were machinewashed with cold tap water and dried to constant weight at $60^{\circ} \mathrm{C}$.

The constants for immediately $(a)$ and slowly $(b)$ degradable fractions of the experimental feeds and the degradation rate $(c)$ for $b$ were computed (MCDONALD 1981) on the basis of the degradation values obtained as a function of time.

\section{Measurement of feed intake and diet digestibility}

To estimate the feed intake, each animal was housed individually in feeding pens for 14 days at the end of 
the experiment. During the intake measurement period, the refused feeds were removed and weighed once a day before morning feeding.

The apparent digestibilities of the diets were determined by a six-day total collection of faeces of the individual animals at the end of the experiment.

Intake of dietary metabolizable energy (ME) was estimated according to the equation (VAN DER HoNING et al. 1977):

$\mathrm{ME}, \mathrm{MJ}=15.06 \mathrm{x} \mathrm{kg}$ digestible organic matter.

\section{Animal weighing}

The animals were weighed at the beginning of the experiment and thereafter every two weeks, and also at the end of the experiment. The weighing was conducted at two consecutive days, and the mean of the two weighings was used. A regression equation was fitted to the two-weekly live weight values in order to calculate the average live weight gain over the experimental period.

\section{Statistical analysis}

The feed intake, digestibility and animal growth data were analyzed according to ANOVA using dietary treatment and block as class variables, and initial live weight as a covariate. The effect of the dietary treatment was further partitioned using the following orthogonial contrasts: diet $\mathrm{H}$ vs. others; diet W vs. other supplemented diets; $\operatorname{diet} \mathrm{C}$ vs. $\operatorname{diet}$ $\mathrm{L}$ and $\mathrm{T}$; and $\operatorname{diet} \mathrm{L}$ vs. $\operatorname{diet} \mathrm{T}$.

\section{Results}

Protein content and rumen degradability were higher and NDF content lower in leucaena roughage and wheat middling as compared to the other feeds (Table 1).

The total DM intake (Table 2) was lowest $(\mathrm{P}<0.01)$ for the unsupplemented control diet (diet $\mathrm{H})$ and highest for the wheat middling supplemented diet (diet W). The differences between the supplemented diets were not, however, statistically significant $(\mathrm{P}>0.05)$. Except for tagasaste, the animals consumed all the supplements on offer. The refusal of tagasaste was one third of the offered amount. Supplementary feeding always resulted in a clear reduction in basal hay intake. The average hay

Table 1. Chemical composition and rumen degradability of the experimental feeds $\left(\mathrm{g} \mathrm{kg}^{-1}\right.$ dry matter, DM).

\begin{tabular}{|c|c|c|c|c|c|}
\hline & $\begin{array}{c}\text { Grass } \\
\text { hay }\end{array}$ & $\begin{array}{l}\text { Wheat } \\
\text { middling }\end{array}$ & $\begin{array}{l}\text { Cowpea } \\
\text { hay }\end{array}$ & $\begin{array}{c}\text { Leucaena } \\
\text { forage }\end{array}$ & $\begin{array}{c}\text { Tagasaste } \\
\text { forage }\end{array}$ \\
\hline \multicolumn{6}{|c|}{ Chemical composition } \\
\hline Organic matter & 902 & 954 & 897 & 900 & 956 \\
\hline NDF & 760 & 368 & 563 & 368 & 592 \\
\hline ADF & 407 & 112 & 460 & 262 & 426 \\
\hline ADL & 67 & 27 & 77 & 77 & 99 \\
\hline Crude protein & 63 & 199 & 128 & 218 & 148 \\
\hline \multicolumn{6}{|c|}{ Degradation constants of DM } \\
\hline$a$ & 97 & 360 & 161 & 271 & 202 \\
\hline$b$ & 286 & 342 & 457 & 356 & 364 \\
\hline$c$ & 0.049 & 0.079 & 0.048 & 0.062 & 0.074 \\
\hline
\end{tabular}

Table 2. Daily feed intake (kg DM) and nutrient consumption $(\mathrm{kg})$ by crossbred steers given grass hay alone $(\mathrm{H})$ or supplemented with wheat middling $(\mathrm{W})$, cowpea hay $(\mathrm{C})$, leucaena $(\mathrm{L})$ or tagasaste $(\mathrm{T})$ forages.

\begin{tabular}{|c|c|c|c|c|c|c|c|c|c|c|}
\hline & \multicolumn{6}{|c|}{ Diet } & \multicolumn{4}{|c|}{ Statistical significance } \\
\hline & $\mathrm{H}$ & W & $\mathrm{C}$ & L & $\mathrm{T}$ & SEM & $\begin{array}{l}\text { H vs. } \\
\text { others }\end{array}$ & $\begin{array}{l}\text { W vs. } \\
\text { C,L,T }\end{array}$ & $\begin{array}{l}\text { C vs. } \\
\mathrm{L}, \mathrm{T}\end{array}$ & $\begin{array}{l}\text { L vs. } \\
\text { T }\end{array}$ \\
\hline Hay & 4.05 & 3.78 & 3.47 & 3.58 & 3.38 & 0.182 & $*$ & NS & NS & NS \\
\hline Supplement & - & 1.26 & 1.27 & 1.30 & 0.88 & - & - & - & - & - \\
\hline Total & 4.05 & 5.00 & 4.70 & 4.83 & 4.28 & 0.190 & ** & NS & NS & NS \\
\hline $\mathrm{OM}$ & 3.63 & 4.55 & 4.21 & 4.34 & 3.93 & 0.176 & $* *$ & NS & NS & NS \\
\hline NDF & 3.06 & 3.29 & 3.32 & 3.16 & 3.12 & 0.152 & NS & NS & NS & NS \\
\hline CP & 0.25 & 0.48 & 0.37 & 0.50 & 0.35 & 0.016 & $* * *$ & $* *$ & ** & ** \\
\hline ME, MJ & 21.5 & 38.3 & 27.7 & 37.1 & 25.4 & 2.37 & ** & * & NS & * \\
\hline
\end{tabular}


intake on diet $\mathrm{H}$ was $7-20 \%$ higher $(\mathrm{P}<0.05)$ compared to the hay intake on the supplemented diets. Crude protein intake was highest on diet L. The share of the supplementary protein was $0,52,44$, 57 and $37 \%$ of the total dietary protein in diets $\mathrm{H}$, $\mathrm{W}, \mathrm{C}, \mathrm{L}$ and T, respectively.

The digestibility of dietary DM was similar in diets $\mathrm{W}$ and $\mathrm{L}$, and it was higher than for the other supplemented diets, but not significantly $(\mathrm{P}>0.05)$ (Table 3). The digestibility of dietary crude protein was significantly $(\mathrm{P}<0.01)$ lower for diet $\mathrm{H}$ than for the other diets. Of supplemented diets, protein digestibility was highest $(\mathrm{P}<0.05)$ for diet $\mathrm{W}$, resulting in the highest intake of digestible CP (Tables 2, $3)$. The leucaena-supplemented diet had a significantly $(\mathrm{P}<0.01)$ higher dietary crude protein digestibility than the tagasaste-supplemented diet.

The highest live weight gains were recorded for diet W (Table 4; Figure). It should be noted that the weight gain was very low for diet $\mathrm{T}$, even lower than for the unsupplemented diet $\mathrm{H}$. On the other hand, the differences in weight gains between diets $\mathrm{W}$ and $\mathrm{L}$ were relatively small.

\section{Discussion}

The use of multipurpose trees as supplementary feeds for ruminants fed on low-quality basal diets provide a potential solution to problems in ruminant nutrition on smallholder farms in tropical or sub-tropical countries. Cowpea, which is also an important source of protein for human consumption in developing countries, could be another alternative to be used as a good-quality cattle feed when harvested as hay. These supplements, and consequently the diets in this experiment, differed in their nitrogen content. Therefore, this study was aimed at contributing to practical on-farm feedingt, and its findings can accordingly be used as recommendations in this respects.

There are a number of reports on the nutritive value of cowpea hay for ruminants, but the work

Table 3. Diet digestibility in crossbred steers given grass hay alone $(\mathrm{H})$ or supplemented with wheat middling (W), cowpea hay $(\mathrm{C})$, leucaena $(\mathrm{L})$ or tagasaste $(\mathrm{T})$ forages.

\begin{tabular}{|c|c|c|c|c|c|c|c|c|c|c|}
\hline & \multicolumn{5}{|c|}{ Diet } & \multicolumn{5}{|c|}{ Statistical significance } \\
\hline & $\mathrm{H}$ & W & $\mathrm{C}$ & L & $\mathrm{T}$ & SEM & $\begin{array}{c}\text { H vs. } \\
\text { others }\end{array}$ & $\begin{array}{l}\text { W vs. } \\
C, L, T\end{array}$ & $\begin{array}{r}\text { C vs. } \\
\text { L, T }\end{array}$ & $\begin{array}{r}\text { L vs. } \\
T\end{array}$ \\
\hline DM & 0.362 & 0.509 & 0.404 & 0.520 & 0.396 & 0.0366 & * & NS & NS & NS \\
\hline $\mathrm{OM}$ & 0.388 & 0.542 & 0.427 & 0.542 & 0.424 & 0.0368 & * & NS & NS & NS \\
\hline NDF & 0.390 & 0.484 & 0.390 & 0.480 & 0.410 & 0.0440 & NS & NS & NS & NS \\
\hline $\mathrm{CP}$ & 0.385 & 0.644 & 0.477 & 0.603 & 0.443 & 0.0361 & ** & * & NS & * \\
\hline
\end{tabular}

Table 4. Initial and final live weights $(\mathrm{kg})$ and the average daily weight gain $(\mathrm{g})$ by regression in crossbred steers given grass hay alone $(\mathrm{H})$, or supplemented with wheat middling $(\mathrm{W})$, cowpea hay $(\mathrm{C})$, leucaena $(\mathrm{L})$ or tagasaste $(\mathrm{T})$ forages.

\begin{tabular}{|c|c|c|c|c|c|c|c|c|c|c|}
\hline & \multicolumn{5}{|c|}{ Diet } & & \multicolumn{4}{|c|}{ Statistical significance } \\
\hline & $\mathrm{H}$ & W & $\mathrm{C}$ & L & $\mathrm{T}$ & SEM & $\begin{array}{l}\text { H vs. } \\
\text { others }\end{array}$ & $\begin{array}{l}\text { W vs. } \\
\text { C,L,T }\end{array}$ & $\begin{array}{r}\text { C vs. } \\
\mathrm{L}, \mathrm{T}\end{array}$ & $\begin{array}{r}\text { L vs. } \\
T\end{array}$ \\
\hline \multicolumn{11}{|l|}{ Live weight } \\
\hline Initial & 138 & 143 & 147 & 141 & 137 & 5.6 & NS & NS & NS & NS \\
\hline Final & 150 & 180 & 170 & 179 & 141 & 6.3 & ** & $*$ & NS & $* * *$ \\
\hline Daily weight gain & 86 & 411 & 236 & 371 & 62 & 28.4 & $* * *$ & $* * *$ & NS & *** \\
\hline
\end{tabular}




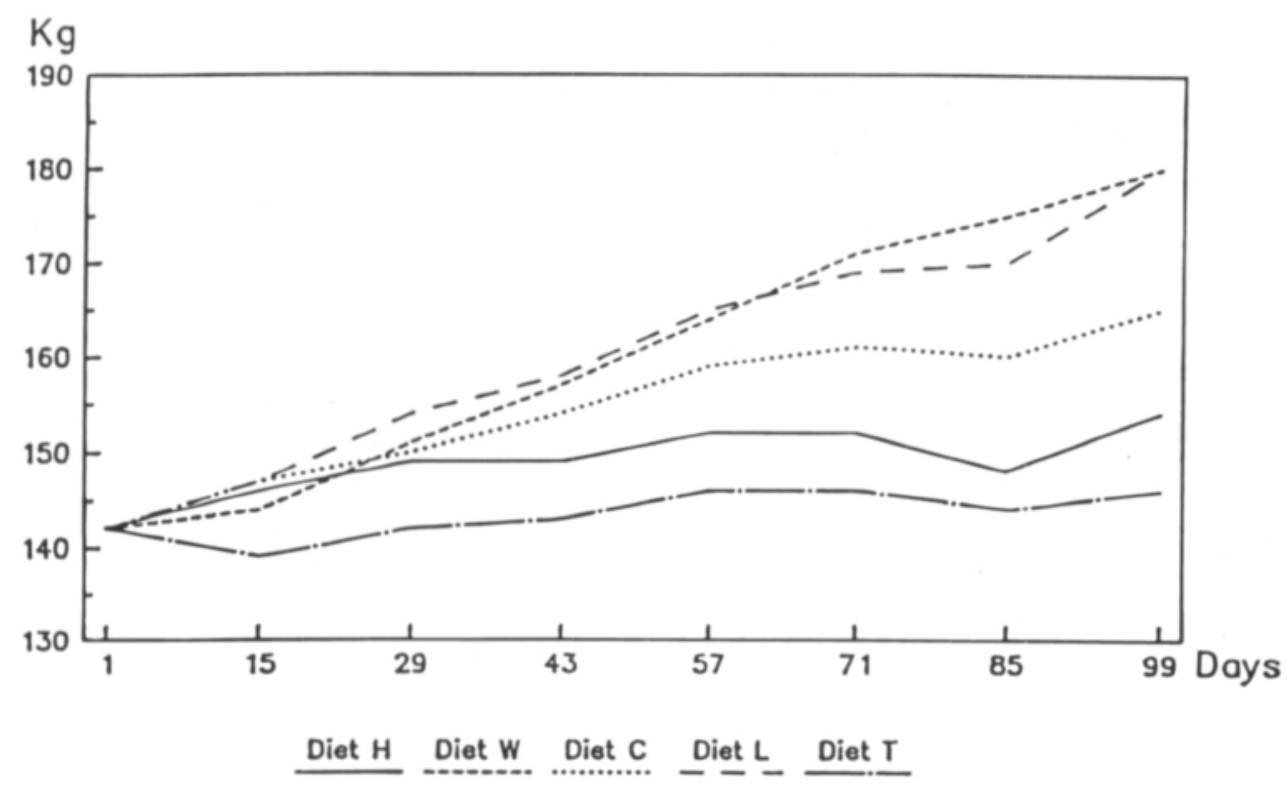

Fig. 1. Animal live weight changes on experimental diets. Grass hay diets were unsupplemented $(\mathrm{H})$ or supplemented with wheat middling (W), cowpea hay (C), wilted leucaena forage (L) or wilted tagasaste forage (T).

has often been based on comparisons between cowpea varieties and stages of plant maturity (GuPTA et al. 1976, 1989; TABUBALIYA et al. 1975). Comparative research between cowpea and other supplementary feeds is scarce. In the present experiment, the potential rumen degradability $(a+b)$ of cowpea hay was found to be quite good and similar to leucaena forage (Table 1). The total DM intake was high with cowpea, but the daily live weight gain was clearly lower than for concentrate or leucaena-supplemented diets (Table 4, Figure).

Although there are a number of published reports on the toxicity of leucaena as a ruminant feed due to its mimosine content (e.g. Alvarez et al. 1978; SAUCEDO et al. 1980; Holmes 1981), many reports conclude that fresh leucaena fodder is a palatable and nutritious feed for ruminants (e.g. ADDY and Thomas 1977; Hulman et al. 1978; Sobale et al. 1978; Flores et al. 1979; BENGE1980). The daily weight gain in the present experiment $(0.37 \mathrm{~kg})$ is in line with the result $(0.46 \mathrm{~kg})$ in a 90 -day experiment by SoBALE et al. (1978). The latter study was made using Holstein x Gir crossbred bull calves fed on a mixture of sorghum straw and molasses ad libitum, supplemented with green leucaena which was restricted to meet the crude protein requirements of the animals.

Tagasaste is a novel feed for ruminants, and related experiments with cattle have not been published so far. The few reports dealing with its nutritional value describe it as a promising feed for small ruminants (see e.g. BORENS and POPPI 1990). In this experiment, the crude protein content of tagasaste forage was found to be rather high, but it was clearly lower than that of leucaena. Rumen degradation was low for all the feeds.

The lower value for constant $a$ indicated that tagasaste had smaller proportion of rapidly degraded fraction than leucaena. No report has been published on nutritionally harmful compounds that could impair the utilization of the feed nutrients in the tagasaste supplemented diet. The content of tannins in tagasaste forage is low (KHALILI and VARVIKKO 1992).

Animal performance with tagasaste feeding has not, however, corresponded to its apparently 
favourable chemical composition (McGowAN et al. 1988; Borens and PopPI 1990). In line with the results of a previous experiment with lactating Friesian $x$ Zebu crossbred dairy cows (VARVIKKO and KHALILI 1992), the rate of refusals of tagasaste forage was high also in the present experiment (Table 3). Both stems and leaves were refused, but the proportion of stems in the refusals was higher. These findings contradict the previous observation that small ruminants have a high preference for tagasaste (LAMBERT et al. 1989a).

In the present study, the wilted leucaena forage in diet $\mathrm{L}$ was found to provide a total dietary crude protein content which was equal to that in diet W. The supplements in both diets $\mathrm{W}$ and $\mathrm{L}$ provided more than half of the total dietary protein. However, wheat middling was superior in feeding value, supporting a significantly $(\mathrm{P}<0.001)$ higher daily live weight gain than for the other supplements.

On an equal DM intake basis, wilted leucaena forage supplementation resulted in a daily live weight gain close to that of animals on the wheat middling-supplemented diet. Live weight gain was clearly higher with leucaena than with cowpea supplementation, and it was sixfold compared to the weight gain with the tagasaste containing diet. The leaf-to-stem ratio was more favourable in leucaena forage than in tagasaste forage. It is likely that the lower fibre content of leucaena forage allowed its more efficient utilization in the rumen. In this experiment, the daily gain with the tagasaste diet was even lower than with the unsupplemented diet H.

With the initial supplementation level of $1 \%$ of live weight, no sign of toxicity was observed for any of the diets during the 100-day experimental period. The present results with growing steers and previous observations with dairy cows (VARVIKKO and KHALILI 1992) suggest that palatability may be a major problem in feeding tagasaste to cattle.

The ME and crude protein intake was highest for diet $\mathrm{W}$, followed by diets $\mathrm{L}, \mathrm{C}, \mathrm{T}$ and $\mathrm{H}$ in descending order (Table 2 ). The order was practically the same for the live weight gains (diets W, L, C, H and $\mathrm{T}$, respectively; Table 3). In accordance with NRC (1989) requirements, the crude protein and ME supply supported daily gains of nearly $0.5 \mathrm{~kg}$ on the wheat middling and leucaena forage supplemented diets only.

Based on the results of this experiment, the supplementary feeds used can be ranked according to their nutritional value in practical feeding as follows: wheat middling, leucaena forage, cowpea hay and tagasaste forage. Leucaena forage provided supplementary nutrients to an almost equal degree as wheat middling. Accordingly, it may be concluded that leucaena forage is a good choice in supplementing the low quality basal roughage hay, if by-products of wheat middling type are not available. Cowpea hay also appears satisfactory. In spite of its apparently good nutritional composition, tagasaste forage in the diet did not improve the feeding value of the low-quality basal diet, probably due to the animals' reluctance to consume it.

Acknowledgments. The authors wish to thank the staff at Debre Zeit Station and ILCA Headquarters for their technical assistance. The financial support by the Finnish International Development Agency (FINNIDA) is gratefully acknowledged. 


\section{References}

ADDY,B.L. \& Tномаs,D. 1977. Intensive fattening of beef cattle by stall feeding on the Lilongwe plain, Malawi. II. Utilization of crop by-products and leucaena. Trop. Anim. Health and Prod. 9: 191-196.

Alvarez,F.J., Wilson,A. \& PrestonT.R. 1977. Leucaena leucocephala as a combined sourse of protein and roughage for steers fattened on molasses/urea. Trop. Anim. Prod. 2: 288-291.

BENGE,M.D. 1980. Leucaena leucocephala: an excellent feed for livestock. Technical Series Bulletin, no 25. Agricultural Technology for Developing Countries (USA). 23 p.

BorEnS,F.M.P \& PopPI D.P. 1990. The nutritive value of tagasaste (Chamaecytisus palmensis), a leguminous tree. Anim. Feed Sci. Technol. 28, 275-292.

FloresJ.F., StobBs,T.H. \& Minson,D.J. 1979. The influence of the legume Leucaena leucocephala and formal-casein on the production and composition of milk from grazing cows. J. Agric. Sci., Cambridge, 92: 351-357.

GoERING,H.K. \& VAN Soest,P.J. 1970. Forage fibre analyses. U.S.D.A. Agriculture Handbook No. 379, pp.1-20.

Gupta,P.C., Kriple Singh, Randhir Singh \& PRADHAN,K. 1976. Studies on the nutritive value of cowpea. Ind. J. Anim. Sci. 46: 122-125.

Gupta,B.K., Malik, N.S., Sohoo, M.S. \& BhardwaJ,B.L. 1989. Comparative nutritive value of cowpea varieties in Buffaloes. Ind. J. Anim. Nutr. 6: 150-153.

HoLmes,J.H.G. 1981. Toxicity of Leucaena leucocephala for steers in the wet tropics. Trop. Anim. Health Prod. 13: 94-100.

Honing,Y., Van Der, Steg,A. \& Van Der Es, A.J.H. 1977. Feed evaluation for dairy cows: tests on the system proposed in the Netherlands. Livest. Prod. Sci. 4: 57-67.

Hulman,B. Emyr OWEN \& Preston,T.R. 1978. Comparison of Leucaena leucocephala and groundnut cake as protein sources for beef cattle fed ad libitum molasses/urea in Mauritius. Trop. Anim. Prod. 3: 1-8.

KHALILI,H. \& VARVIKKo,T. 1992. Effect of replacement of concentrate mix by wilted sesbania (Sesbania sesban) forage on diet digestibility, rumen fermentation and milk production in Friesian $\mathrm{x}$ Zebu (Boran) crossbred cows fed low quality native hay. Anim. Feed Sci. Technol. 36: 275-286.

LAmbert,M.G., Jung, G.A. \& Costall,D.A. 1989. Forage shrubs in North Island hill country. 1. Forage digestibility. New Zealand J. Agric. Res. 32: 477-483.

Lambert,M.G., Jung,G.A., Fletcher,R.H., Budding,P.J. \& Costall ,D.A. 1989a. Forage shrubs in North Island hill country. 2. Sheep and goat preferences. New Zealand J. Agric. Res. 32: 485-490.

MCDONALD,I. 1981. A revised model for the estimation of protein degradability in the rumen. J. Agric. Sci., Camb. 96: 251-252.

McGowan,A.A., Robinson,I. \& Moate,P. 1988. Comparison of liveweight gain and mineral metabolism of sheep fed pasture or tagasaste. Proc. Austral. Soc. Anim. Prod. 17: 230-233.

NRC 1989. Nutrient Requirement of Dairy Cattle. Sixth Revised Edition. Update 1989. National Research Council, National Academy Press, Washington D.C. 157 p

Saucedo,G., Alvarez,F.J., Ariga,A. \& Jimenez,N. 1980. Leucaena leucocephala as a source of protein for calves reared in a restricted suckling system. Trop. Anim. Prod. 5: 232-235

Seyoum Bediye \& Zinash Sileshi 1989. The composition of Ethiopian Feeds. Research Report No. 6. Institute of Agricultural Research, Addis Ababa, Ethiopia. 12 p.

Sobale,B.N., Kharat, S.T., Prasad, V.L., Joshi,A.L., RANGNEKAR,D.V. \& DeshmuKh,S.S. 1978. Nutritive value of Leucaena leucocephala for growing bull calves. Trop. Anim. Health Prod. 10: 237-241.

Tabubaliya,T.S., Patel,C.A. \& Patel,A.S. 1975. Nutritional evaluation of cowpea varieties. Ind. J. Nutr. Diet. 12:366-371. Ind. J. Anim. Sci. 55: 808-812.

VARVIKKo, T. \& KhALILI, H. 1992. Wilted tagasaste (Chamaecytisus palmensis) forage as a replacement for a concentrate supplement for lactating crossbred Friesian $x$ Zebu (Boran) dairy cows fed low quality native hay. Anim. Feed Sci. Technol. 36, in press.

Manuscript received November 1991

Tuomo Varvikko

Hannele Khalili

Seamus Crosse

International Livestock Centre for Africa

P.O. Box 5689

Addis Abeba, Ethiopia

Tuomo Varvikko

Present address:

Agricultural Research Centre of Finland

Institute of Animal Production

SF-31600 Jokioinen, Finland 


\title{
SELOSTUS
}

\section{Lehmänpavun, kahden esikuivatun Leguminosae-rehupuun sekä vehnäleseen vertailu lisärehuna friisiläis-zebu -risteytyssonnivasikoiden ruokinnassa}

\author{
Tuomo Varvikko, Hannele Khalili ja Seamus Crosse \\ International Livestock Centre for Africa (ILCA)
}

Sata päivää kestäneessä kasvukokeessa, joka tehtiin 40 friisiläis-zebu -risteytyssonnivasikalla, verrattiin lehmänpapua (Vigna unquiculata), kahta esikuivattua Leguminosaerehupuuta, leucaena (Leucaena leucocphala) ja tagasaste (Chamaecytisys palmensis), sekä vehnälesettä vasikoiden lisärehuna käytännőn tilatason ruokinnassa. Valitut rehut ovat kotoperäisiă tai yleisesti paikallisesti tuotettavia märehtijän rehuja tropiikin ja sub-tropiikin maissa. Lisärehua annettiin ilmakuivana $1.5 \mathrm{~kg}$ täydentämään luonnonvaraiseen niittyheinään perustuvaa ruokintaa, jossa myös päivittäinen kivennäisten saanti oli varmistettu.

Johtopäătős kokeen syönti- ja kasvutuloksista oli, että vehnäleseen jälkeen tuotantovaikutukseltaan paras lisärehu oli leucaena. Toinen rehupuu tagasaste antoi huonoimman kasvutuloksen, kontrolliryhmä mukaan lukien. Huono kasvutulos ehkä johtui suureksi osaksi siitä, että eläimet jättivät noin kolmasosan tarjotusta tagasastesta syömättä. Muilla lisärehuilla ei havaittu syönti- tai maittavuusongelmia.

Selostettu koe tehtiin Afrikan kansainvälisessä kotieläintutkimuskeskuksessa ILCA:ssa, Addis Abebassa, Etiopiassa. Koe on osa Suomen Ulkoasiainministeriön Kehitysyhteistyöosaston rahoittamaa lypsykarjan ruokinnan kehittämisprojektia Etiopian ylänköalueilla. 